\title{
Taboos and Euphemistic Idioms in Ejagham: A Sociopragmatic Analysis
}

\author{
Gabriel MBA*, Besong Charlotte \\ Department of African Languages and Linguistics, University of Yaoundé
}

\author{
DOI: $\underline{10.36348 / \mathrm{sij} 11.2021 . v 04 \mathrm{i} 02.002}$ \\ | Received: 16.01.2021 | Accepted: 25.01.2021 | Published: 09.02.2021
}

*Corresponding author: Gabriel MBA

\section{Abstract}

A People's culture is embedded in its language. This is the case of the Ejagham community and its language, an Ekoid Bantu language of the Benue Congo family spoken in the Manyu Division of the South West Region of Cameroon and in the Cross River state of Nigeria [1]. Culture observes some restricted domains which are not talked about freely, generally known as taboos. The Ejagham speakers, in order to communicate, substitute these areas of restriction with the use of less offensive expressions known as euphemisms; thereby avoiding the occurrence of taboos. This article highlights some taboo related areas in the Ejagham culture, and shows the euphemistic idioms used by Ejagham speakers to talk about certain restricted areas (death, marriage, sex) during verbal interactions. Social cohesion is therefore guaranteed as face saving strategies are used.

Keywords: taboo, euphemism, idiom, pragmatics

\section{LIST OF ABBREVIATIONS AND SYMBOLS}
[1] W: Word translation
[2] LM: Literal meaning
[7] $\mathrm{S}=$ Speaker
[3] “ " = gloss
[4] $\mathrm{ETC}=$ Etcetera
[8] $\mathrm{H}=$ Hearer
[5] FTA = Face Threatening Acts
[6] ()$=$ Explanation
[9] fig. Figure.

Copyright (c) 2021 The Author(s): This is an open-access article distributed under the terms of the Creative Commons Attribution 4.0 International License (CC BY-NC 4.0) which permits unrestricted use, distribution, and reproduction in any medium for non-commercial use provided the original author and source are credited.

\section{INTRODUCTION}

Language is an integral part of the culture of a community and does not only convey information but also expresses a social phenomenon or a social behavior. Aspects like taboos and euphemisms remain one of the major phenomena of language use in a society. In every social interaction, interlocutors have different intentions. Sometimes their intentions are centered on some culturally, religiously or socially restricted aspects, making it difficult for them to convey their message as it ought to be. Such restrictions have to do with what can be considered as taboos.

This paper seeks to highlight the aspect of taboo that exists in the Ejagham language and how idioms on euphemism are used to make these taboo areas more palatable and more acceptable without hurting anyone's feelings directly or indirectly. Specific domains of verbal interactions which are fertile in euphemisms are exploited (marriage, sex, death) and an eclectic theoretical and analytical approach (politeness theory, face theory, cooperative principles, communication contexts) are used to address the question.

\section{1-The concepts}

. Idioms have been defined in many ways by different scholars. Trask [2] sees idioms as "a fixed expression whose meaning is not guessable from the meaning of its parts". Frasser [3] considers an idiom as "a single constituent or a series of constituents, whose semantic interpretation is independent of the formatives which compose it". Richards et al. [4] in the Longman Dictionary of Applied Linguistics, define an idiom as "an expression which functions as a single unit and whose meaning cannot be worked out from its separate parts". According to Bolinger [5]. Idioms, are "groups of words with set meanings that cannot be calculated by adding up the separate meanings of the parts". Ghazala [6] gives a more comprehensive definition of idioms, considered as "special, metaphorical, fixed phrases whose meanings and forms are not negotiable". Thus, expressions like idioms rely on the context for a proper understanding of the meaning.

Taboo dates to the start of human existence and has been defined in various ways. Bussman [7] sees a taboo as "a term that is avoided for religious, political or sexual reasons and is usually replaced by euphemism. According to Raharddjo [8], a taboo is a 
linguistic phenomenon which occurs in most languages because every member of the society has different ways to express his or her mind in language. Moreover, it depends very much on moral values, norms and culture that have been grown and developed in one society which exists and are agreed together. Wardhaugh [9] states that taboo is related to cultural meaning which is expressed in language: used to avoid saying certain things.

Etymologically, euphemism is derived from the Greek word "eu" meaning "good" and "pheme" meaning "speak" literally relating to as speaking with good words. Basically, the use of euphemisms is motivated to avoid taboo words. From this understanding, linguists advanced the definition of euphemism in varied ways. Euphemism can be defined as an act of substituting an offensive or unpleasant word for a more pleasant one, thereby veneering the truth by using kind words [10, 11]. Allan and Burridge [12] suggest a pragmatic approach towards understanding euphemisms, which is simultaneously both speakeroriented and hearer-oriented. In this light, "An euphemism is used as an alternative to a less preferred expression in order to avoid possible loss of face, either one's own or, by giving offense, that of the audience, or of some third party". In other words, euphemism is a face-saving mechanism which emphasizes cooperation in a conversation. Usually, to avoid taboo words, interlocutors employ what is called euphemism, which can be defined as "a pleasant replacement for an objectionable word that has pejorative connotations" Bussman [7]. Cruse [13], states that euphemism is "an expression that refers to something that people hesitate to mention lest it causes offence, but which lessens the offensiveness by referring indirectly in some way".

\section{2-Reviewing literature on Taboos}

Much has been done on the research on taboo or euphemism. Works conducted by Epoge [14], Qanbar [15], Ahmad et al. [16], Mbaya [17] and Mwanambuyu [18] can be mentioned.

Epoge [14] studied euphemism in Cameroon English. According to this study, euphemism has to do with sweet talking or deception. Sweet talking because, they soften or disguise unpleasant words in a reality and deceptive because it serves as a deliberate dishonest way of using words to make what is bad seems good or tolerable. However, even though the study holds that there exist unavoidable truths; euphemistic terms for this study are used both by the $\mathrm{S}$ (Speaker) and $\mathrm{H}$ (Hearer), not to remind the other of an unpleasant act.

Qanbar [15] scrutinized taboos in the Arab society of Yemen. He investigates linguistic taboos, with respect to their relationship with the social context in which they are used. Similar to the current study, it examines different taboos and the strategies used by
Yemeni speakers to avoid the use of these forbidden words, among which are euphemisms.

In the same vein, Ahmed et al. [16] based their study on the linguistic taboos in the Pashtoon society in Pakistan, while considering religious, cultural and social factors that prompted the use of taboos. They offered an explanation as to why certain words are considered taboos in this society and why they are accompanied by particular conventionally fixed words.

From a different end, Mbaya [17] carried out a descriptive study of a custom in Oromo culture (Ethiopia) known under the name of laguu or lagacha, which involves avoiding the mention of the names of the persons who are related by marriage. According to the study, husbands, wives and in-laws avoid using their respective names and as such coin several other forms to substitute them.

For Mwanambuyu [18], examination of Silozi euphemisms from a sociopragmatic perspective was done. The study revealed that Silozi euphemisms occur in a wide range of relationships and it is commonly used among the old than the young. Forms of euphemisms and their patterns depend on the social distance between the participants, their relative social statuses, age, occupation, gender and power of the $S$ and $\mathrm{H}$. Also, context and $\mathrm{S}$ intention are indispensable in the understanding of euphemisms. Mwanambuyu [18] inspires the current study on how factors like context and speaker's intention, through the politeness, face and conversational analysis theories can aid in the understanding of taboos and euphemisms.

Inspired by the above reviewed literature, the current study was able to highlight some of the areas in the Ejagham context, which are considered as taboo sensitive; and also, how these unpleasant terms (taboo) can be replaced with more polite terms (euphemisms). Also, the pragmatic theories used in these studies impact the current study; because context remains one of the principal factors in a study of this nature. Euphemisms and taboos are better understood and appreciated by people who share same social and cultural background or context.

Research on taboos espouses the language pragmatic domain, essential for its full comprehension. Therefore, a quick glance at its theoretical background is obvious in this study.

\section{3-Pragmatics and its theoretical relevance}

Pragmatics can be defined as a branch of study concerned with the ability of language users to pair sentences with context in which they would be appropriate [19]. For Mey [20] "pragmatics studies the use of language in human communication as determined by the conditions of society". Context remains a key factor in a pragmatic study. It is "any 
Gabriel MBA \& Besong Charlotte., Sch Int J Linguist Lit, Feb, 2021; 4(2): 39-47

background knowledge assumed to be shared by the speaker and the hearer which contributes to the hearer's interpretation of what the speaker means by a given utterance" [21]. Adegbija [22] views context as "the relevant aspects of physical or social setting of an utterance or discourse". Pragmatics has given birth to a number of theories, the following being relevant for this study: theories of politeness, face saving strategies, cooperative maxims and context

According to Grice [21], through communication, people transfer their ideas, thoughts, beliefs and intentions to one another. However, for a sustainable relationship to develop, participants must cooperate with one another. He propounded some general rules, known as the Gricean maxims, which must be followed for any communication to be smooth. However, a speaker in the violation of these rules may generally create an implicature or a presupposition. Cooperation involves speakers' use of language that is understood by the hearer without creating problems to his or her culture, psychology and physiology. According to Horn [23], "implicature is a component of speaker meaning that constitutes an aspect of what is meant in a speaker's utterance without being part of what is said." In proposing the politeness principle theory, Leech [10] takes into consideration the relationship that exists between the speaker and the listener, as politeness helps to maintain a healthy and cordial relationship between them. In this principle, he proposes eight maxims, which speakers can use in observing politeness. He uses the terms "cost" and "benefit". Cost is usually maximum on the side of the speaker and minimum to the listener, while benefits provide minimum benefit to the speaker and maximum benefit to the listener. Brown and Levinson [19], based their politeness theory on Goffman's 1955 concept of face which refers to the public self-image of a person or the emotional and social sense of self that everyone has and expects everyone else to recognize. An individual's face can be threatened by what they termed face threatening acts (FTAs), as every individual has two types of face: the negative and the positive faces. An individual's positive face is observed when his image is respected, while his negative face is observed when his positive self- image is threatened. The above theories remain indispensable for this study. The relevance of the cooperative principle can be judged in examining how Ejagham speakers cooperate to construct meaningful units in a particular context, and in the analysis of the meaning of euphemism, especially when an implicature is created. The politeness principle and theory facilitate the analysis of the data for this study, by describing how Ejagham speakers replace taboos with euphemism. These theories help in determining how these speakers use politeness strategies to mitigate the face threats of using taboos. This is done by minimizing the use of taboos, while maximizing the use of euphemisms.
4-Ejagham taboo data collection, treatment and analysis

The data for this study was derived through participant observation in some communicative events like marriages, village meetings, age group meetings, disputes settlements, cabinet meetings and funeral ceremonies. The essential aspects of the data are treated and presented in form of a text, according to the subject matter it portrays, with its surrounding phrases, word translation (w) and the literal meaning ( $\mathrm{lm}$ ). The data is analyzed based on the particular context, alongside the indicated relevant theoretical frameworks deemed appropriate for the purpose of the study (politeness, face, context and Gricean maxims theories). Using simple percentages, the frequency of the euphemisms used in the different taboo related areas were calculated. This assessment paved the way for the evaluation of how the Ejagham people behave vis-a-vis taboos. Death, marriage, sex and sex related issues seem to be the main taboo domains wherein death has the highest number of occurrences in the use of euphemisms (13) followed by sex (4) and marriage the lowest (2).

The diagram below explains these occurrences better.

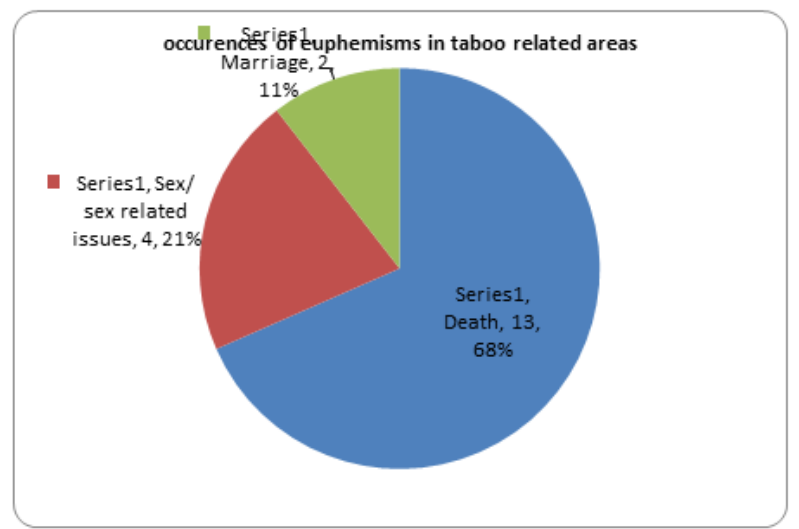

Fig-1: Occurrences of euphemisms in taboo related areas

The pie chart above indicates the percentages of the different taboo topics of the study, in relation to how euphemistic language is used when expressing them. The highest taboo topic in the Ejagham language that makes use of euphemistic language is death with a percentage of $68 \%$. The second set of euphemisms with a high number of occurrences is those expressing sex and sex related issues. This may be because sex is a respectable area. In addition, the issue of marriage, though it falls under taboo topics in Ejagham, has the least number of occurrences. The reason could be that it is not so much strict as the other topics expressing taboo. Marriage is a joyful event, and even if people do not talk about it freely, there is always the tendency of an accompanying joy that may cause speakers to use the bald-on record strategy of politeness propounded by Brown and Levinson [19]. 
Gabriel MBA \& Besong Charlotte., Sch Int J Linguist Lit, Feb, 2021; 4(2): 39-47

\section{5-Taboo selected areas and significance in Ejagham community /culture}

Studying taboo topics in Ejagham language and the idioms that are used to talk about them through the use of euphemism first of all requires an understanding of some areas which are restricted or forbidden. These restricted areas are: sex and sex related topics (body parts and organs, menstrual fluid), death, infidelity, marriage etc. This paper limits its scope to three areas.

\subsection{Death as a taboo/ Euphemisms of death}

Generally, in the Ejagham community, death is considered as a transition from one world to another. As such, the dead are treated with much respect when talked about. It is a taboo to talk about the dead carelessly. Therefore, in order to avoid such instances of disrespect, the deads are talked about mostly via the use of euphemisms or indirect expressions, amongst which are idioms.

For example, it is rare to find someone using the usual and most direct expression below to talk about the death of someone.

Taboo: Ké kpó "To die"

In the utterance

ßà kpó

$\mathrm{w}$ : he died

$1 \mathrm{~m}$ : "He is dead"

Instead of using the above, they will employ euphemism idioms like:

1. idiom: àkikù ké $\beta$ Đy nè "For the ancestors to call someone"

In the utterance

àkìkù $\beta$ à $\beta$ ỳn wè

w: devil they called him

$\mathrm{lm}$ : "His ancestors have called him"

In the above expression, àkìù, the singular of which is nkikù is the word used in the community to talk about ghosts, someone who has died or the mortal remains. Also, the word is used to talk about the ancestors. The idiom indicates that the ancestors or the dead have called someone, thus referring to death. This goes with the belief of the people that when one dies, he goes to continue another life with his ancestors who had gone before him.

2. Idiom: ké t $\int$ Èm ánè nsì "To join the ancestors"

In the utterance

"ßà t ţ̀̀m ánè nsì"

w: He join people earth"

$1 \mathrm{~m}$ : "He has joined the ancestors"

Unlike the euphemism in the idiom in one above, which states that the ancestors call someone when they die, here, it is the person who goes to join them. Ánè nsì which is literally translated as people of the ground is a representative of the ancestors. The Ejagham people believe in life after death. This explains why during burials, some people are buried alongside their valuable articles like clothes, pots, hoes, and cutlasses to facilitate a new life in the other world.

3. èlaYà gìm ké khə̀ "For the standing wall to collapse"

In the utterance

$$
\text { Òh! Papa Bernard, èlaYà gìm } \quad \beta e ́ \quad \text { khò }
$$

w: "Oh! Papa Bernard, wall standing it break!" lm: "oh, papa Bernard, the standing wall has collapsed"

This euphemism is used to refer to the death of a person who was very influential in the family or society. By using an analogy of 'a standing wall' èlarà gìm, it symbolizes the importance of the person in the family or society. A wall is seen symbolically as a strong surface that is raised to support a building. That is why when one of the walls of a building collapses, there is risk of the whole building crumbling.

\section{Idiom: ké tfèn "To pass" \\ In the utterance.

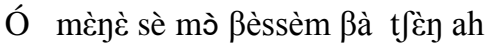

w: you know that child Bessem's has passed?

lm: "Do you know that Bessem's child passed away?"

This euphemism equally symbolizes death in the Ejagham community but specifically the death of a still birth. The child is believed to have passed because he was actually supposed to live in the actual world before going to the world of the ancestors at an old age. However, this newborn did not wait to experience the realities of the world but moved straight to join the ancestors.

\section{Idiom: ké tà "To be lost or missing"}

In the utterance

arrey $\beta$ à tà.

w: arrey he lost

$1 \mathrm{~m}$ : "Arrey is lost/ missing"

This is equally used as a euphemism of death among the Ejagham people. The idea of something being lost literally signifies that it cannot be found. Consequently, when people use this idiom, they are referring to the death of somebody who is considered to have been missing and will never be found. However, if after the death of somebody in the family, a member of that family puts to birth a baby of a similar sex to the deceased, it is believed that the ancestors have sent to them the dead person to continue his or her works. Most often, the baby is named after the one who died. The 
Gabriel MBA \& Besong Charlotte., Sch Int J Linguist Lit, Feb, 2021; 4(2): 39-47

exception to this is if the person had a bad reputation. This is to avoid causing the innocent child to suffer, because the people believe that names have power on their bearers.

\section{Idiom: ké kwélé "To return"}

In the utterance

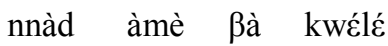

w: in-law my he returned

lm: "My in-law has returned"

This is another euphemism that is used to talk about death in the Ejagham community. The idea of returning comes from the fact that death is considered in the community as the return to one's origin which is from their ancestors. Thus, after death, one simply goes back to his origin.

7. Idiom: ké tyep ánè ndzem “To give one's back to others"

In the utterance

nè nó $\beta a ̀ ~ t g \varepsilon p$ wòt ndłsm

w: man that he turn us back

$1 \mathrm{~m}$ : "That man has given is his back"

The idea of turning ones back on others is close to its literal representation. It has an underlying meaning of death, which describes the phenomenon [26], based on what happens when the people communicate with their ancestors. There is a tradition of old that when someone dies, the members of his or her family have the possibility of invoking his or her spirit to know why he died or to get advice from him. To do this, the members visit a soothsayer with any item that belongs to the dead person. He uses this to invoke his or her spirit, and when he finally appears; he or she turns her face and only show them his or her back. It was from this that the euphemism originated.

8. Idiom: à $\mathrm{t} \varepsilon \mathrm{p} \beta$ à ndzem $\beta$ à kwèn wè

w: Turning of back they carried him

lm: "Those who turn their backs, have called him"

This idiom is similar to the euphemism above but for the fact that the representation of this euphemism is that it is the ancestors who carry the dead person away and not he going to join them. This means that when one's own existence in life has come to an end his or her ancestors come and carry one away.

9. Idiom: ßèsene $\beta$ à kwèn àßò ygày

w: death it carried hands chest

$1 \mathrm{~m}$ : "Death has carried the hands on the chest"

This explains death in the Ejagham community but more precisely the way a person who has died is placed before being buried. The euphemism comes from the way the mortal remains is laid in the coffin, usually with their two hands folded over their chest. Thus, when a person dies and the speaker wants to mention it using a euphemistic expression, the above is used.

10. Idiom: ké dzì kà nsì ákìkù "To go to the land of ghosts" / "To die"

In the utterance

ènònò mò ne ndùm jè wè ßà ḑì kà nsì ákìkù w: Good child man man see him he gone to land ghost

$\mathrm{lm}$ : "A handsome man has just gone to the land of ghosts"

The euphemism is suggestive of the fact that when one dies, they are travelling or going to the land of the dead to begin another life there. This accounts for why this euphemism is used to indicate that one has embarked on a journey to this land beyond. During burial, the family accompanies him with necessary equipment that will enable him to start a new life with ease.

11. Idiom: "ké dzì "To go (to die)"
In the utterance
jò Ayuk ßà dzì jò dzì
w: So Ayuk he go but gone
lm: "So Ayuk has gone just like that?

The verb "ké dzì" "to go" is an infinitive verb used in its literal form, to talk about displacing oneself from one place to another. However, this same verb can serve as a euphemism when talking about the death of someone. This is because the dead are believed to have been displaced or gone somewhere. Thus, in the euphemistic idiom "ké dłì' is significant of death and not literally to go somewhere. For a better understanding, such an expression needs to be interpreted in its actual context.

12. Idiom: ké màYà ánè "To leave people" è èh, pàpá Bernard $\beta a ̀$ màYà wòt ò ò ò

w: e eh papa Bernard he left us ooo $1 \mathrm{~m}$ : "Eh papa Bernard has left us oooh"

In this euphemism, leaving someone's presence literally means to walk out on them or to excuse yourself from others. However, its underlying meaning represents a fact to die. This euphemistic idiom is used because when one dies, all that is left behind is memories and not the actual presence of the person. The use of this thus makes an inference of the eradication of a person from the face of the earth and no one will be able to see them again in their original state, except as ancestors. 
Gabriel MBA \& Besong Charlotte., Sch Int J Linguist Lit, Feb, 2021; 4(2): 39-47

13. Idiom: ké ḑì éḑè "To go on a journey"

In the utterance

papa nò nè ykwí ngo osier ßà dzì édzè

w: Papa of man big there under he gone journey

lm: "That grand-father down there has gone on a journey"

This euphemism of going on a journey is the same as the explanation given in above. The one who dies is believed to have fulfilled the understanding of death as a transition from this life; where one moves to live in the world beyond. Thus, when this idiom is used, the dead person is believed to have gone on a journey to his or her ancestors.

\subsection{Sex/ sex related issues as a taboo/ Euphemisms used}

Sex and sex related issues fall under another domain of taboo topics. Sex generally is considered sacred among the Ejagham people. It is culturally a way of consolidating and consuming the love between two people who have been joined by bond of marriage, with procreation being at the finality of the act. Contrarily, if two people are found consuming this act whereas they have not been united by marriage, it becomes a sacrilege that brings about ill-luck or punishment of some kind. Sex and all that centers on it is sacred among the Ejagham people. So, they do not talk about it freely like any other common topic of discussion. For Example, the expressions below are considered as a taboo and not frequently used to talk about sex:

ké jòm "To have sex" ké nòm nè nkjé nè "To have sex with someone's wife" ké nòm nè ndúm nè "To have sex with someone's husband".

However, to talk about sex and sex related aspects, interlocutors use the following:

\author{
1. Idiom : ké gbò énòy "To fall asleep" \\ In the utterance \\ Bà gbò énòy \\ w: He fall asleep. \\ $1 \mathrm{~m}$ : "He has fallen asleep."
}

Adultery is a taboo in the Ejagham community because a woman during her marriage is consecrated just for her husband. Sleeping with other men or another man while still under her husband's roof often brings misfortune and ill-luck to the husband. That is why if a woman is suspected of or caught committing adultery, the group of elderly women known as "mawu" convoke her for judgment, and if found guilty, she will be punished severely. On the man's part, when he discovers or suspects that his wife is having extra marital affairs, he ceases to sleep with his wife or even eat from her pot so as to avoid or stay away from the supposed misfortune which may befall him. When a woman denies the accusations of adultery, she is made to swear and if found guilty the consequences may be more serious. However, since adultery is a taboo topic in the Ejagham community, people refuse to talk about it freely or openly.

From the above explanation, "to fall asleep" is not the same as one feeling dizzy or tipsy and going into his or her room to rest. Falling asleep here is used as a euphemism of slipping into another person's bed (adultery). The verb "to fall" is significant of the sin committed by the individual, and such a sin is fallen into just by getting into the bed of another.

2. idiom: ké nàklé bìdzí “To dirty one's skin"

In the utterance

à ké wà kpè ßàYà nè ndùm, à ké ḑĕ à nàklà bìdzí

w: she to find any kind man man, she to walk she dirty skin

$1 \mathrm{~m}$ : "She dates just any man, she moves about dirtying her body."

The act of "dirtying one's skin", is another euphemism for adultery. When a married person is sleeping with another, it is equivalent to becoming dirty or unclean. It is normal for one to get dirty in the literal sense, if mud, oil, ink or any other dirty substance is thrown on them. However, because sex is a sacred symbol between married couples in the Ejagham community, sleeping with another person is considered as dirtying of self. Thus, when the speaker uses such idioms, they are subtly referring to such an abomination, which can only be understood in context.

3. Idiom: bìdzì ké fá nè "for the body to be on heat" "To be anxious to meet the opposite sex" (making love)

In the utterance

"mò nè ndum nó, èßù nè nkjè á tyèn tyèn kâ mkpè èjè, bìdzì é ké tgá wè"

w: child man man that, time man woman she pass pass at side his, body it is pass him"

lm: What a man! Immediately a woman passes by him, he is on heat".

This idiom is used as a euphemism indicating uncontrollable sexual desires in someone. It was used during a youth gathering after they had returned from farm clearing and had to evaluate the day. While they were for the meeting, the attention of the "wine pourer" was needed, but he had left and followed a lady who had just passed on the road. The members started grumbling about his flirtatious attitude and criticized him through the idiom. For one's body to be on heat is a euphemistic way to indicate the fact that a person is eager to make love to another of the opposite sex. 
Gabriel MBA \& Besong Charlotte., Sch Int J Linguist Lit, Feb, 2021; 4(2): 39-47

4. idiom: Ké nòyYé "To sleep" (to make love/ have sex)

In the utterance:

ßàk é dzì nònYé

w: come we go sleep

$1 \mathrm{~m}$ : "Come let us make love"

This idiom is used as a euphemism to express the desire to meet with the opposite sex (make love/ have sex). It can be used when parents are around their children and want to talk about sex without scandalizing them. Literally, the euphemism Ké nònYé "to sleep" is indicative of the act of going to bed to rest. However, its context of use creates an implicature of wanting to make love. There is thus need for common previous knowledge or information shared by the speaker and the listener to understand the underlying meaning.

\subsection{Marriage as a taboo / Euphemisms on marriage}

Marriage is talked about covertly and considered as a taboo in the Ejagham community especially when those involved, the speaker(s) want (s) to pay a kind of respect to those concern about this union directly or indirectly. In the past, marriage was not an issue of joke or an issue handled with triviality. It involved a careful study carried out by both parents of the couple to be sure if the two families are fit to be together. As such, marriage was not spoken of overtly until conclusions and agreements were reached by the two people and their families. An example of one of the rarest expressions that are used in talking about marriage amongst the Ejagham, (because it is not too pleasant) is:

\section{Ké kó ébé "To get married" Ké kó nè kà ébé "To marry someone"}

Nevertheless, there are more pleasant ways of saying the above, such as:

1. Idiom: ké blò nḑù nè
$\mathrm{W}$ : to curse house man

Lm: "To curse or spoil somebody's house" (to get married is someone's house)

\section{In the utterance ndzù éjà jì $n$ ké $\beta a ̀$ blò. w: House your this, I to come spoil $\mathrm{lm}$ : "I am coming to spoil your house"}

The literal meaning indicates the desire of someone to curse another person's house but figuratively it expresses one's desire to get married in a person's house. It is used as a euphemism for informing the hearer about the desire of the speaker to get married in the Hearer's house. The use of this euphemism is to assert the superiority of the man whose daughter's hand is solicited for marriage. It is a taboo in the Ejagham community for a younger person to impose an action or a request on an elder. Thus, overtly asking for a lady's hand in marriage from the father may sound disrespectful. Preferably, interlocutors choose to use euphemism like that above to remain polite all along.
2. Idiom: ké blò ódzù w: to curse plums
lm: "To curse /spoil a plum tree" (for one to be married)

In the utterance

ò kà tyàYà átè ò sí ygó, ódzù w: you not play play you reach there, plums those they cursed

$1 \mathrm{~m}$ : "You should not play to that extent, that plum tree has been cursed."

The literal meaning makes reference to putting an injunction on a plum tree. This is a general practice in the Ejagham community to scare away thieves from one's farm. It is done by putting some traditional charms tied on a rope and hung on a stick. When this happens, the tree or the farmland is considered to be cursed, spoiled or forbidden from any other person, except the owner. However, the underlying meaning in this euphemism is indicative of a person who is married. When a young lady is married, she can no longer have a relationship with another man other that her husband. So, the speaker is warning the hearer about the plum tree that has been cursed (the lady).

\section{Taboo and ejagham societal behaviours}

One of the most popular hypotheses that is proposed by Edward Sapir and Benjamin Lee, and known as the Sapir -Whorf hypothesis, as cited by Wardhaugh [24], says that the structure of language can affect the society by influence or even control them. The existence of taboos and the use of euphemisms by Ejagham speakers shape the way they behave towards these in the community. As Enright stated, "A language without euphemisms would be a defective instrument of communication": [11]. When they want to talk about some sensitive, unpleasant, offensive or taboo topics, yet want to be polite at the same time, euphemisms serve as the only way out. For example, looking at the topics of death, sex/ sex related issues and marriage, which are considered as unpleasant, restricted, or sensitive areas; when such areas become unavoidable in an interaction, they are substituted by different euphemistic terms. See (fig. 1).

Moreover, "euphemisms are embedded so deeply in our language that few of us, even those who pride themselves on being plain spoken, ever get through a day without using them", [25]. Likewise, in the Ejagham community, using euphemism is an active pragmatic strategy of the speakers at a certain time and a certain situation (context), to carefully use words that will enhance communication between $\mathrm{S}$ and $\mathrm{H}$. These people, via their language show a sound understanding 
Gabriel MBA \& Besong Charlotte., Sch Int J Linguist Lit, Feb, 2021; 4(2): 39-47

to taboos, such that naturally they use euphemisms to make what they want to say more appealing.

For instance, it is rare, almost impossible and culturally unaccepted, for someone to use the taboo expression for death ké kpò "to die", to announce or give information about someone who has given up the ghost. They will agreeably use euphemisms like: àkìkù ké ßəy nè, "For the ancestors to call someone" or ké ḑì édzè, "to go on a journey", in place of the coarse, painful or offensive one. This is argued by the fact that the philosophical view of the meaning of life by the Ejagham people is their belief in a life after death (a transition from one world to another). This is the more reason why the dead are talked about with much reverence.

Among these people, the cultural conditioning of some linguistic expressions brings forth the need to avoid a certain aspect of a word, which if used in its actual state, will violate the norms. In such a circumstance, the way out consists in softening the word, by opting for a less explicit way of saying it. This generally is with the intention of neither hurting the hearer, nor the speaker himself. For example, talking about the act of adultery or fornication, the usual expression ké nòm "to have sex" is replaced by the euphemistic form ké nàklé bìdzí “ to dirty one's skin” or Ké nònYé "to sleep" (to make love/ have sex). The fact that Ejagham people have as a moral principle, not to fornicate or commit adultery, because sex for them is sacred, explains why they feel uncomfortable talking about such, except by using euphemisms.

Aside from the use of euphemisms, silence and the general avoidance of taboo terms is another way by which the Ejagham people sometimes react towards taboo topics. For instance, in a situation where someone brings up a taboo topic like sex in the presence of children, the $\mathrm{H}$ in order not to violate the norms simply keeps silent. This immediately alerts the $\mathrm{S}$ that what he or she has said is not acceptable, especially in the particular context.

Considering that native speakers of Ejagham are expected to know how to tactfully replace unpleasant taboos with pleasant euphemisms, whoever violates the use of this is consequently referred to as hybrid. This is usually with the derogatory words ànè ókárá, directly translated as "people of English". Moral principles, philosophy of life and cultural settings intervene as social parameters in verbal interactions and especially in taboo related domains. These toe the line of pragmatic theories of communication grounded on politeness, face saving strategies, cooperative maxims and context issues.

\section{CONCLUSION}

Language is considered as a carrier of the culture of a people as revealed by this presentation based on the Ejagham language and community. There are many topics like death, sex/ sex related topics and marriage which are not talked about freely because they are considered offensive or impolite. However, Ejagham interlocutors may choose to use these words on such topics as they are, following the bald-on record strategy of Brown and Levinson [19] whereby, both speakers and listeners tacitly agree that the relevance of face demands may be suspended. This may occur when factors governing the aspects of power, distance and social ranking between the interlocutors are favourable. For example, there is not so much politeness between people of same age, same social rank or status. These people may by-pass all aspects of politeness and thus use the taboo topics as they are. Nonetheless, interlocutors may still substitute these taboo expressions with euphemism, when there is a high desire for respecting or saving the hearers' positive face as proposed in the positive politeness strategy of Brown and Levinson or politeness principle of Leech [10].

It can thus be perceived that Ejagham speakers observe a degree of sensitivity towards taboo related topics like death, sex, or even marriage. This can be expounded by the fact that they pay a special reverence to their dead, because of their belief in death as a transition.

\section{REFERENCES}

1. Watters, J. R. (1981). A Phonology and Morphology of Ejagham with notes on dialect variation, Ph.D thesis; University of California.

2. Trask, R.L. (2002). Language and Linguistics. The key concepts. London. UK variation, a $\mathrm{Ph} . \mathrm{D}$ dissertation, University of California, Los Angeles.

3. Frasser, B. (1970). A note on vice versa, linguistic inquiry 1: 277-8

4. Richard. (1985). Longman Dictionary of Applied Linguistics. London, Longman.

5. Bolinger, D. (1975). Aspects of Language $2^{\text {nd }}$ Edition New York : Harcourt, Brace, Jovanovich

6. Shidham, V. B., Chang, C. C., Shidham, G., Ghazala, F., Lindholm, P. F., Kampalath, B., ... \& Komorowski, R. (2003). Colon biopsies for evaluation of acute graft-versus-host disease (AGVHD) in allogeneic bone marrow transplant patients. BMC gastroenterology, 3(1), 5.

7. Bussman, H. (2006). Rutledge dictionary of language and linguistics (Translated and edited by Gregory T., \& Kerstin, K.) London: Routlege.

8. Rohardjo, M. (2002). Relung-Relung Bahasa. Yogyarta: Aditia Media

9. Wardhough, R. (1986). An Introduction to sociolinguistics. Oxford: Basil Blackwel ltd

10. Leech, G. (1983). Principle of Pragmatics, Longman Group Limited, England.

11. Enright, D. (Ed.). (1985). Fair of speech: The uses of euphemism. Oxford: Oxford University Press 
Gabriel MBA \& Besong Charlotte., Sch Int J Linguist Lit, Feb, 2021; 4(2): 39-47

12. Allan, K., \& Burridge, K. (2006). Forbidden words: Taboo and the censoring of language, Cambridge: Cambridge University press.

13. Cruse, A. (2006). A glossary of semantics and pragmatics, Edinburgh: Edinburgh university press.

14. Epoge, N. (2013). "Euphemism in Cameroon English; sweet talking or deception?" international journal of innovative interdisciplinary Research, 2, 1, 1-10.

15. Qanbar, N. (2011). "A sociolinguistic study of the linguistic taboos in the Yemeni Society", modern journal of Applied Linguistics, 3,2,86-104

16. Ahmad. (2013). "A sociolinguistic study of Linguistic taboos in the Pashtoon society" International Researcher, 2, 1, 35-41

17. Mbaya, M. (2002). "Linguistic taboo in African marriage context: A study of the Oromo laguu", Nordic Journal of African studies, 11, 2,224-235

18. Mwanambuyu, C. (2011). A sociopragmatic Analysis of Silozi Euphemisms, The university of Zambia, Lusaka.
19. Brown, P., \& Levinson, S. (1978). "Universals in Language Usage, Politeness

20. MEY, J.L. (2001). Pragmatics: An introduction.

21. Grice, P. (1975). "Logic and Conversation" in COLE, P. and MORGAN, J. (eds), Syntactic and Semantics, volume 3, Speech Acts, Academic Press, New York, 41-58.

22. Adegbija, E. (1999)." Tit-bits on Discourse Analysis and Pragmatics" in Adegbija E. (ed) The English Language and Literature in English. MEL Department, University of Illorin, Nigeria pp 156205

23. Horn, L.R. (2006). The Handbook of Pragmatics. Yale University.

24. Wardhough, R. (2006). An Introduction to socioinguistics (Fifth Edition): Oxford Blackwell publishes Ltd.

25. Rawson, H. (1981). A dictionary of euphemisms and other doubletalk. New York: Crown Publish

26. Phenomenon" in GOODY, E.N (ed.) Questions and Politeness: strategies in social interaction: Cambridge, Cambridge University Press 56 - 289. 